Univerzitet u Beogradu
Poljoprivredni fakultet
Institut za poljoprivrednu tehniku
Naučni časopis
POLJOPRIVREDNA TEHNIKA
Godina XLVI
Broj 3., 2021.
Strane: $40-48$
Faculty of Agriculture
AGRICULTURAL ENGINEERING
Year XLVI
Institute of Agricultural Engineering
No. 3., 2021.
pp: $40-48$

\title{
DETERMINATION OF MAIN PARAMETERS OF ISOBUS SYSTEM BASED AGRICULTURAL MACHINERY MANAGEMENT
}

\author{
László Magó*1, Gligorevic Kosta ${ }^{2}$, Drazic Milan², Oljaca V. Mico² \\ ${ }^{1}$ Institute of Technology, Hungarian University of Agriculture and Life Sciences, \\ Páter K. u. 1., Gödöllö, H-2103, Republic of Hungary \\ ${ }^{2}$ Faculty of Agriculture, University of Belgrade, Deprtament of Agricultural \\ Engineering;11080 Belgrade, Republic of Serbia
}

\begin{abstract}
ISO organization (https://www.iso.org) in early 90s defined an industry standard for the communication protocol among electronic devices of different manufacturers of agricultural machines. After that, all of the market actors recognised that this technology would be very important for agricultural electronics. The appearance of ISOBUS products in the market was in the mid-2000s. ISOBUS description could be found in ISO-11783 (https://www.iso.org).

Through the standards and the related technical background, the production processes and the operations could be followed and monitored by the extensive Data Management. Farmers' and users legitimate needs and developing goal is to elaborate a decision support systems that follow-up the utilisation of the machines and ensure the quality of operations. For this purpose, it is essential to determine which technical, economical, technological parameters detection, measurement, transmission, processing, and evaluation becomes necessary.

In our work, we reviewed which mechanical characteristic, settings are monitored within the ISOBUS system by the major machine manufacturers. We developed the system of parameters and derived features that provide effective farm-, and land-management in case of attached equipment for spreading of input materials, plant protection and tillage implements.
\end{abstract}

Keywords: ISOBUS, data management, machinery management, agricultural mechanisation, product development

\footnotetext{
*Corresponding author. E-mail: Mago.Laszlo@uni-mate.hu
} 


\section{INTRODUCTION}

\subsection{ISO11783 standard and the foundation of the AEF}

After almost 20 years of application and development the ISOBUS (as defined in the standard ISO11783) has become a key element in the design of modern agricultural machinery, $[4,11,13,15]$

There is a lot of factors which prevent a smooth and fast introduction of the ISOBUS products in the market:

- the complexity of the standard;

- the rapid evolution of digital technology;

- the lifecycle of components of agricultural tractors and related return of investments; The first two items mainly drove the creation of an industry consortium called AEF (Agricultural Electronics Foundation). This allowed manufacturers to create a common interpretation of the standard when applied to real products, [7]

Agricultural Industry Electronics Foundation, the AEF, was founded in October 2008 in Frankfurt at the VDMA. The founding members were 7 equipment manufacturers (John Deere, Grimme, Pöttinger, CNH, AGCO, Claas, Kverneland) and 2 associations (VDMA and AEM). AEF's aim was and is to provide resources and know-how for the increased use of electronics and electrical systems in mobile Farming Equipment. In the first years of its existence, it was clear that a succession of important tasks associated with ISO 11783 (ISOBUS) formed the main focus of AEF's work, [10, 11, 15]

Since its founding in 2008, the AEF has grown to a mature and independent Industry Foundation with over 200 members, [1].

ISO 11783 is a complex and large electronics protocol standard based on CAN and SAEJ1939 standards, extended for the Agricultural Industry. The standard consists of 14 different parts and more than thousands of specification pages, [5, 14, 15]

\subsection{ISOBUS Functionalities}

For increased transparency towards the end-customers as well as to developers, the AEF has defined the so-called ISOBUS Functionalities that are now also the basis for the certification of ISOBUS products. The Functionalities encapsulate the different Control Functions on the ISOBUS network, such as the Terminal, the Tractor ECU, an Auxiliary device or a Task Controller, [10, 14]

After a first period in which all the ISOBus sections release levels were defined in a certain ISO11783 implementation level it become evident that a more practical approach was needed to address the increasingly complexity. Eight main functionalities, each of them with its set of ISO11783 sections release, were then released by AEF, covering the main functional aspects addressed by the standard (Figure 1). 


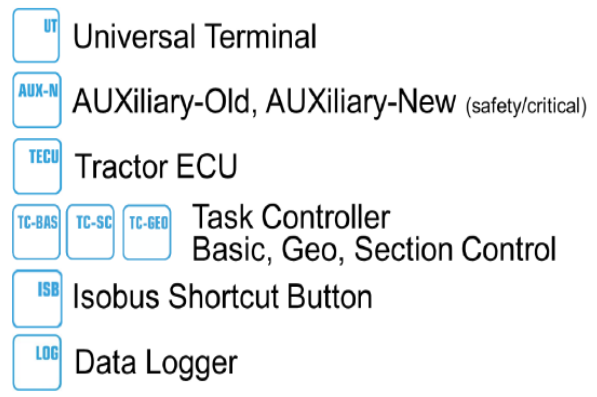

Figure 1. Today ISOBUS released functionalities, [7].

The AEF has released the following Functionalities that can be certified today by the Conformance Test:

- UT - Universal Terminal. The capability of operating an implement with any terminal. The capability of using one terminal for operating different implements.

- AUX - Auxiliary Control. Additional control elements, such as a joystick, that facilitate the operation of complex equipment.

- TC-BAS - Task Controller - Basic. Describes the documentation of total values that are relevant for the work performed. The implement provides the values. For the exchange of data between farm management system and Task Controller the ISOXML data format is used.

- TC-GEO - Task Controller - GEO-based. Additional capability of acquiring location based data - or planning of location-based jobs, as for example by means of variable rate application maps.

- TS-SC - Task Controller - Section Control. Automatic switching of sections, as with a sprayer or seeder, based on GPS position and desired degree of overlap.

- TECU - Tractor ECU. The tractor ECU is the tractor's interface to the ISOBUS. This provides information, such as speed, power take-off RPM, etc on the ISOBUS for use by the implement.

- ISB - ISOBUS Shortcut Button. A button present on a Terminal, or in the Tractor cabin, to be used to send a global message to all connected Control Functions on the ISOBUS to go to an Idle/Shortcut state. This Functionality is not to be seen as an emergency button! The Functionality approach is flexible, and new functionalities that come up in the future can easily be added once the Guidelines are defined and released. Functionalities that are currently under development are for example: TIM / ISOBUS Automation and the TC-LOG, [2]

\section{MATERIAL AND METHOD}

\subsection{Data Management}

Data Management facilitates the exchange of data with the mobile equipment in the field. Through this functionality the user gets his data into a management system for registration purposes and further future planning. 
Newly planned data can be generated by a decision support advisory systems and taken back into the farming equipment for planned field tasks and operations through for example a wireless service or telematics portal of the manufacturer, [10].

\subsection{Connectivity}

The end-customers, i.e. the farmers and contractors, expect a seamless connectivity of implements and tractors, regarding all systems and data, both in the field on his machines as well as to other software and services. An 'open' mind to connectivity with competitors and suppliers of Farm Management Software solutions and other Decision Management services is therefore a must for all companies and equipment manufacturers, [9].

\subsection{Future Directions}

Future challenges in ISOBUS development are focused at three points:

1. COPL (Cost Optimized Physical Layer):

Cost optimization allowing a higher diffusion of the ISOBUS technology (also more suitable for smaller machines). The goal is to reach lower volumes and smaller application.

2. WIC (Wireless Infield Communication):

3. HIS (High Speed ISOBUS):

- Distributed high-resolution position/correction signals.

- Digital Video Systems.

- Improved Service and Diagnosis (flash ECUs, Log-files, raw data streams for debugging).

- Mobile Internet on ISOBUS for dedicated server/client requests.

- High Voltage data Connection.

As technology evolves, manufacturers must take advantage of new opportunities with the end goal of providing farmers with a higher productive, higher quality and more efficient farming cycle, [3, 6, 11, 12, 14, 15].

\section{RESULTS}

\subsection{Overview of selected parameters for processing and monitoring of products of the market's leading agricultural machinery manufacturers}

In first step of the research work the measured and processed parameters of most significant attached working equipment was defined.

The sprayers, fertilizer spreaders and seed drills (including towed-, and attached version, and also the direct-, and mulch sowing machines) and the ploughs were selected. 
For machines listed in the measurement and processing of the measured values of the following parameters were determined:

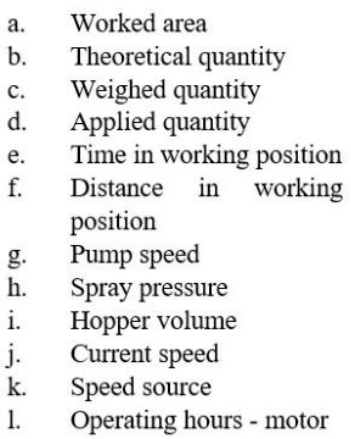

$\begin{array}{ll}\text { m. } & \text { Current track width } \\ \text { n. } & \text { Motor torque in \% } \\ \text { o. } & \text { Motor speed in rpm } \\ \text { p. } & \text { Average consumption } \\ & \text { AdBlue in 1/ha } \\ \text { q. } & \text { Average consumption } \\ & \text { Diesel in } 1 / \text { ha } \\ \text { r. } & \text { Current blower fan speed } \\ \text { s. } & \text { Blower fan speed setpoint } \\ \text { t. } & \text { Minimum speed } \\ \text { u. } & \text { Maximum speed } \\ \text { v. } & \text { Target speed }\end{array}$

w. Spread rate actual value

x. Spread rate setpoint

y. Working position

z. Setpoint in per cent

aa. Theoretical residual quantity

bb. Hopper content

cc. Working width

\subsection{The determination of monitored technical-technological parameters during the works of tractor and attached working machine combination}

The next phase of work was the definition of the groups and subgroups of the technical-, and technological parameters which could be measured, processed and displayed during the works of tractor and attached working machine combination. These characteristics were classified into four main groups (Table 1.).

Table 1. The main groups of the technical and technological parameters

\begin{tabular}{|l|l|l}
\hline Quality of work & Power, and capacity-utilisation & Work safety
\end{tabular}

We denoted subgroups within the main groups, according to specificity, and the selected parameters were grouped in this way. The physical parameters which are the base of monitored technical and technological characteristics are presented in the Table 2 according to above illustrated classification.

To assure the quality of work it is important to ensure adequate working depth, tracking of the dispensed amount of input materials and analysis of energy consumption.

In terms of the power, and capacity-utilisation the area, the time, and the quantity (by volume or weight) proves to be key factors.

The work safety can be provided by the in time detection of crash, injury or by detection of early signs of developing malfunctions e.g. the formation of irregular resonance, or limitation of overload, and the monitoring of drivers behaviour.

From the users part it is essential to take into account the cost. From this perspective the labour cost, the machine work cost, and the cost of inputs are most determinative and it is primary to follow-up them. 
Table 2.Recommended follow-up ISOBUS values

\begin{tabular}{|c|c|c|c|}
\hline Quality of work & $\begin{array}{l}\text { Power, and } \\
\text { capacity-utilisation }\end{array}$ & Work safety & Cost \\
\hline $\begin{array}{ll}\text { - } & \text { Working depth } \\
\text { - } & \text { Measured value: } \\
\text { - } & \text { traction, drawbar } \\
\text { deformation, } \\
\text { - } & \text { slip, } \\
\text { - } & \text { pitching angle of } \\
\text { tractor }\end{array}$ & $\begin{array}{ll} & \text { Area } \\
- & \text { Measured value: } \\
\text { - } & \text { trip length, } \\
\text { - } & \text { Current speed, } \\
\text { - } & \text { Average speed, } \\
\text { attached machine } & \text { width, } \\
\text { - } & \text { adjusted working } \\
& \text { width staging), } \\
\text { - } & \begin{array}{l}\text { Direction of } \\
\text { operation } \\
\text { (coordinates) }\end{array}\end{array}$ & 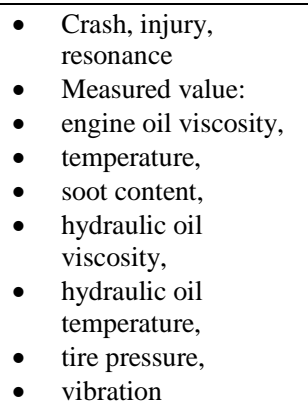 & $\begin{array}{l}\text { - Labour } \\
\text { - Measured value: } \\
\text { - ID of vehicle card }\end{array}$ \\
\hline $\begin{array}{ll}\text { - } & \text { Dispensed amount of } \\
& \text { input material } \\
\text { - } & \text { Measured value: } \\
\text { - } & \text { PTO speed, } \\
\text { - } & \text { pump flow, } \\
\text { - } & \text { seed hopper weight, } \\
\text { - } & \text { seed plates speed, } \\
& \text { weight, spreading disc } \\
& \text { speed }\end{array}$ & $\begin{array}{ll}- & \text { Time } \\
\text { - } & \text { Measured value: } \\
\text { - } & \text { shift time, } \\
\text { - } & \text { engine operating } \\
& \text { hours }\end{array}$ & $\begin{array}{ll} & \text { Overload } \\
- & \text { Measured value: } \\
\text { - } & \text { gear, } \\
\text { - } & \text { motor temperature, } \\
& \text { (workint hitch height } \\
\text { - } & \text { drawbar defth), } \\
\text { - } & \text { PTO deformation, }\end{array}$ & $\begin{array}{l}\text { - Machine work } \\
\text { - Measured value: } \\
\text { - Work operation } \\
\text { code, } \\
\text { - Work operation } \\
\text { date, } \\
\text { - duration of work } \\
\text { operations, } \\
\text { - correction factor } \\
\text { of work } \\
\text { operations }\end{array}$ \\
\hline $\begin{array}{l}\text { - } \text { Energy consumption } \\
\text { - } \text { Measured value: } \\
\text { - } \text { actual fuel } \\
\text { consumption, } \\
\text { - } \quad \text { exhaust gas } \\
\text { temperature, } \\
\text { - number of fuel card, } \\
\text { - quantity and time of } \\
\text { refuelling }\end{array}$ & $\begin{array}{ll}\text { - } & \text { Volume or weight } \\
\text { - } & \text { Measured value: } \\
\text { - } & \text { seed hopper weight, } \\
\text { - } & \text { seed plates speed, } \\
& \text { fertiliser hopper } \\
& \text { weight, } \\
\text { - } & \text { spreading disc } \\
& \text { speed }\end{array}$ & 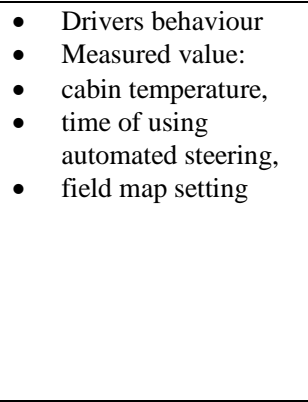 & $\begin{array}{l}\text { - Input material } \\
\text { - Measured value: } \\
\text { - amount of } \\
\text { spreaded input } \\
\text { materials, } \\
\text { - area, distance } \times \\
\text { working width } \\
\text { - unit price of } \\
\text { inputs, } \\
\text { - duration of the } \\
\text { service, } \\
\text { - cost of service }\end{array}$ \\
\hline
\end{tabular}

\section{CONCLUSION AND RECOMMENDATIONS}

The technical solutions provided by the ISOBUS system - registering of the operating parameters of power machine and attached equipment - could review not only the technical and service characteristics of operation of each machine.

There is an opportunity to overview the features on farm-management level that are the effective core devices for corporate governance, for efficient production and for successful planning too. 
These data in case of high-volume machine fleet, whether it is farm-fleet or contractors fleet, makes transparent the administration of machines and the performed tasks by their. These can be defined as the effective modules of the company's management systems.

From technical approach it is essential to ensure compatibility of ISOBUS communication between the products of different producers, between the power machine and attached implement, and on the level of telemetrical data transfer too. Mostly the European market of agricultural machines is the main market where the multi brand interconnectivity represents the biggest challenge. This innovative market is that where the ISOBUS has the widest application.

\section{Acknowledgement}

This publication has been completed within the framework of Project FIEK_16-1-20160008 Centre for University - Industry Cooperation in Agricultural Informatics (AgIT ICC), the program financed from the NRDI Found.

Activity in publication was completed within the framework of Project $\mathrm{N}^{0} \mathrm{TR}-31051$, from Ministry of Education, Science, and Tehnology Development of the R. of Serbia, implementation and financing of Scientific research in year 2021., between the Faculty of Agriculture in Belgrade and the Ministry of Education, Science and Technological Development of the Republic of Serbia.

\section{REFERENCES}

[1] AEF Website, http://www.aef-online.org .

[2] AEF ISOBUS Database, https://www.aef-isobus-database.org

[3] Bártfai Z., Faust D., Kátai L., Szabó I., Blahunka Z .2017. Terrain Surface Monitoring with IMU Equipped Mobile Robot. Book of Abstracts, $8^{\text {th }}$ Internat. Conference on Biosystems Engineering Tartu, Estonia, 11-13. May 2017. pp. 15.

[4] Benneweis R. K. 2006 Facilitating agriculture automation using standards, 14 p.

[5] International Standard Organization. https://www.iso.org. ISO11783.

[6] Martinov M., Gronauer A., Kosutić S.2018. Highlights of 27th Club of Bologna Meeting 46 Symposium, Proceedings of "Actual Tasks on Agricultural Engineering", Opatija, Croatia, 27. February - 1. March 2018. pp. 19-28.

[7] Mongiardo M. 2017. ISOBus: the Industry Perspective, Meetings Proceedings of the 27th Club of Bologna Members' Meeting Hanover, 12-13 November 2017. pp.14.

[8] Stone M. L., Benneweis R. K., Bergeijk J. V. 2008. Evolution of electronics for mobile agricultural equipment, Transactions of the ASABE, Vol. 51(2): pp. 385-390.

[9] Treiber M., Bernhardt H. 2021. The Nevonex Ecosystem - Implications of an IOT Framework on Automation in the Agricultural Machinery Sector. Proseedings of 48th Symposium "Actual Tasks on Agricultural Engineering", Zagreb, Croatia, pp. 27 - 33.

[10] Vlugt P.,V.D. 2017. ISOBUS: State of the Art and Future Directions, Meetings Proceedings of the 27th Club of Bologna Members' Meeting Hanover, 12-13 November. pp. 12.

[11] Laslo Mago. 2011. Agricultural machines distribution in the Hungary in past ten years. Journal of Agricultural Enginering, Vol 36., No4., pp.77-82. 
[12] Laslo Mago. 2008. Comparison of Technical-Economical Parameters of Machine Utilisation in Different Branch of Plant Production. Journal of Agricultural Enginering.Vol 33., No4., pp. 53-60.

[13] Kosta Gligorević, Mićo V. Oljača, Đukan Vukic, Ivan Zlatanović, Branko Radičević, Miloš Pajić, Rade Radojević, Vladimir M. Oljača, Zoran Dimitrovski. 2009. Application of CANBUS Networks on tractors and working machines. Journal of Agricultural Enginering, Vol 34., No1., pp.115-121.

[14] Mićo V. Oljača, Kosta Gligorević, Milorad Branković, Zoran Dimitrovski, Dragi Tanevski. 2005. Electronic Equipments on Tractors and Working Machines in Functions of Higer Control of Security and Exploatation. Journal of Agricultural Enginering, Vol 30., No1., pp.107-1118.

[15] Oljača V.M., Vukić Đ., Ercegović Đ., Radivojević D., Momirović N., Topisirović G., Gligorević K., Radičević B., Oljača M.V. 2008. Bežični senzori u poljoprivredi danas i buduće perspektive primene. Poljoprivredna tehnika, Vol. 33, No1, pp. 7-20.

\section{ODREĐIVANJE GLAVNIH PARAMETARA SISTEMA ISOBUS KAO OSNOV ZA UPRAVLJANJE POLJOPRIVREDNIM MAŠINAMA}

\section{László Magó, Gligorevic K., Drazic M., Oljaca V.M}

${ }^{1}$ Institute of Technology, Hungarian University of Agriculture and Life Sciences, Páter K. u. 1., Gödöllö, H-2103, Republic of Hungary

${ }^{2}$ Faculty of Agriculture, University of Belgrade, Deprtament of Agricultural Engineering,11080 Belgrade, Republic of Serbia

Sažetak: ISO organizacija (https://www.iso.org) je početkom 90-ih godina definisala industrijski standard za komunikacioni protokol između elektronskih uređaja različitih proizvođača poljoprivrednih mašina.

Nakon toga, svi tržišni akteri prepoznali su da je ova tehnologija veoma važna za elektroniku koja se koristi u poljoprivredi. Pojava proizvoda ISOBUS na tržištu u značajnijem obimu počinje sredinom 2000 -te godine.

Opis ISOBUS tehnologije može se naći u standardu ISO-11783 (https://www.iso.org).

Kroz standarde i odgovarajuću tehničku pozadinu, opsežni menadžment podataka mogao bi pratiti i nadgledati mnogobrojne proizvodne procese i operacije u poljoprivrednoj proizvodnji. Legitimne potrebe poljoprivrednika i drugih korisnika i razvojni cilj je konstrukcija i primena sistema za podršku odlučivanju koji prate upotrebu mašina i osiguravaju kvalitet poslovanja. U tu svrhu je neophodno utvrditi koji tehnički, ekonomski, tehnološki parametri postaju neophodni za otkrivanje, merenje, prenos, obradu i procenu adekvatnih parametara u proizvodnji .

U radu je analizirano koje mehaničke karakteristike i parametre podešavanja u sistemu ISOBUS imaju najznačajniji proizvođači mašina koje se primenjuju u različitim poljoprivrednim operacijama. 
Razvijen je sistem parametara i izvedenih karakteristika koji pružaju efikasno upravljanje poljoprivrednim površinama u slučaju priključene/korišćene opreme za rasipanje izlaznih materijala (seme, đubriva), sredstava za zaštitu bilja i obradu zemljišta.

Ključne reči: ISOBUS, upravljanje podacima, upravljanje mašinama, poljoprivredna mehanizacija, razvoj proizvoda

Prijavljen:

Submitted:

Ispravljen:

Revised:

Prihvaćen:

Accepted:
25.03.2021

20.05.2021

25.05.2021 